\title{
What Is the Place of the Play Between the Essential Needs of Preschool Children According to Preservice Teachers?
}

\author{
Hatice Uysal Bayrak ${ }^{1}$ \\ ${ }^{1}$ Faculty of Education, Nigde Omer Halisdemir University, Nigde, Turkey \\ Correspondence: Hatice Uysal Bayrak, Department of Early Childhood Education, Faculty of Education, Nigde \\ Omer Halisdemir University, 51240, Nigde, Turkey.
}

Received: September 28, 2018

Accepted: October 30, 2018 Online Published: February 26, 2019

doi:10.5539/ies.v12n3p148

URL: https://doi.org/10.5539/ies.v12n3p148

\begin{abstract}
This research aims to reveal the perceptions of the preservice teachers on the play which are among the essential needs of the preschool children. In this descriptive study, a case study which is one of the qualitative research designs was used. 79 preservice teachers attending the third grade in the Classroom Teaching Department of state university in Nigde province in Turkey. Convenience sampling method was used in the selection of the study group. A semi-structured interview form was prepared in order to reveal the perceptions of preservice teachers about the play. Content analysis technique was used for data analysis. At the end of the research, it was determined that the preschool teacher candidates expressed the essential needs of preschool children as nutrition, education and love respectively. The play was ranked as the number four among these needs.
\end{abstract}

Keywords: children, play, preschool

\section{Introduction}

The play forms an important part of a child's life and it prepares the child for the adult world by allowing her/him to develop her/his personality and talents (Egemen, Yılmaz, \& Akil, 2004). Play is a simple pleasure that is a valuable part of childhood (Ginsburg, 2007). Play is not only a fun and spontaneous activity of young children, but also contributes significantly to the psychological development of children (Verenikina, Harris and Lysaght, 2003). The play is considered to be the most appropriate language for the preschoolers to express their dreams, the environment they live in, their feelings and thoughts such as love, jealousy, happiness and hostility (Kamaraj, 2000). Early childhood educators frequently emphasize that children acquire many cognitive skills through play (Lockhart, 2010). The play has a great importance in the realization of learning in children. The play, which guides the lives of preschoolers, also promotes their physical, social and emotional development by providing natural learning environments. The child gains the ability to control her/his body, to hold objects, to comprehend the modes of operation of objects, and to use objects through play activities (Jones, 2007). Jersild explained this by stating that the play is the child's most serious occupation. In this occupation, children exhibit their strengths and skills like an adult (see Kamaraj, 2000). Play can be summarized as the means of developing and entertaining the child, learning, gaining experience, creating, enjoying, being happy, communicating and preparing for adulthood, expressing emotions and all activities that support children's development in every area (Poyraz, 1999). According to Kelly-Vance and Ryalls (2008), play is an entertaining, exciting and motivating activity for children. In addition to being an important part of the daily lives of children, it is a window that offers teaching-learning opportunities and opens up to support their developmental levels. Smiles and laughter accompanying the play confirm the entertaining nature of the play (Johnson, Christie \& Yawkey, 1998).

Throughout history, play has been considered as the most important element in the development of children. There are also opinions that play supports the cognitive, emotional and social development of the children, as well as the opinions that children play for their own good. Not only children but also adolescents and adults can play games in their spare time (Daw, 2009). However, it is often missed out that the play is as enjoyable as it is educational. There are sharp differences of opinion among adults on this topic. Some parents believe that the play contributes to the child's hopes of leap forward in developmental areas, while other parents find the play unnecessary and absurd (Johnson, Christie, \& Yawkey, 1998). In this direction, it has been seen that all kinds of opinions are included in the theories proposed for years. The theories of play are mainly divided into classical (Surplus Energy Consumption, Relaxation, Repetition, Practice) and modern theories (Freud, Erikson, Piaget, Vygotsky, Bruner, Sutton-Smith, 
Singer, Intrinsic Stimulation, Bateson):

Surplus Energy Consumption Theory. According to this theory, the play is the consumption of the surplus energy accumulated in the body. The child achieves a healthy balance when she/he can overcome the excess energy that creates tension on herself/himself. The more children play a game, the healthier they are. The fact that young children run into the playground after a long-term structured activity in a classroom demonstrates the accuracy of this theory (Johnson, Christie \& Yawkey, 1998; MoNE, 2009; Sevinç, 2004).

Relaxation (Recreation, Entertainment) Theory. The play is an ideal way to recollect the energy consumed along with the job. The structured activities wear down the human in cognitive and physical aspects. As a result, there is a need for rest and sleep. The real rest is created by dealing with activities other than daily life tasks, and the individual renews herself/himself in this way. In brief, children are playing games as their relaxation needs arise (Johnson, Christie, \& Yawkey, 1998; Sevinç, 2004).

Repetition (Recapitulation) Theory. According to this theory, children repeat the developmental stages that they observe in the human race through play. The aim of the play is to purify children from primitive instincts that are not necessary in modern adult life. Sports, such as baseball, for example, allow children to play outside and destroy their old hunting instincts to strike with a stick. During the play, the child re-experiences the spiritual and dynamic stages encountered in human life (Johnson, Christie, \& Yawkey, 1998; MoNE, 2009; Sevinç, 2004).

Practice (Initial Trial, Adult Life Preparation) Theory. Every newborn inherits the instincts necessary to survive. The play provides a safe tool for babies of living creatures to practice and develop these vital skills. The aim of the play is to apply the skills required for adult life (Johnson, Christie, \& Yawkey, 1998; Sevinç, 2004; MoNE, 2009).

Freud's Theory. The play is believed to have an important role in the child's emotional development. The child can transfer the negative feelings to another object or person by reversing the roles and becoming an active part. Children between $0-6$ years of age find the opportunity to rehearse their negative feelings and anxieties in the face of the situations of frustration and conflict that may occur in the course of their personality development (Johnson, Christie, \& Yawkey, 1998; Sevinç, 2004; MoNE, 2009).

Erikson's Theory. According to this theory, the play proceeds through stages that reflect the psychosocial development of children. Children create model situations that will help them to cope with emotions, thoughts, events and learn the real life by playing games (Johnson, Christie, \& Yawkey, 1998).

Piaget's Theory. According to this theory, children go through a series of different cognitive stages, and in this process their thinking processes are increasingly similar to those of adults. Children are interested in the type of play that suits their cognitive development level (Nicolopoulou, 2004). In fact, play is a phenomenon in which the child controls these elements through play, combining her/his knowledge, experience and understanding (Sevinç, 2004).

Vygotsky's Theory. According to this theory, play is a means of personal development, which is important in children's social and emotional development and cognitive development. In the play, children can develop themselves in the areas of self-control, self-regulation, motivation, use of language, memory, imagination, obedience to rules, abstaining from self-centeredness and cooperation with others (Bodrova \& Leong, 1996; Johnson, Christie, \& Yawkey, 1998; Nicolopoulou, 2004).

Bruner's Theory. This theory emphasizes how the play increases creativity and flexibility. Children do not have any ambitions to accomplish any purpose while playing, so they can try new and unusual behavior combinations (Johnson, Christie, \& Yawkey, 1998).

Sutton-Smith's Theory. According to this theory, these transformations, which enable the child to get rid of stereotypical mental associations and bring their thoughts together in new and unusual ways, result in a collection of great creative thoughts and associations that can be used later (see Johnson, Christie, \& Yawkey, 1998). Sutton-Smith opposes the idea of Piaget, which states that it is difficult to produce innovation through play, and he argues that producing innovation is a source for ensuring harmony (MoNE, 2009).

Singer's Theory. According to this theory, play and especially creative play is not only a coping mechanism due to emotional maturation as Freud argues and it is not only an assimilation tool because of a defective logic as Piaget suggests, but also a positive force in development. Although the ability to imagine is a developmental phenomenon that develops with age for all children, some children tend to have more imagination than other children. The environment in which the children live, and the way they are raised, arouse their desire for imagination (Johnson, Christie, \& Yawkey, 1998). 
Intrinsic Stimulation Theory. According to this theory, when there is too much stimulation, stimulation increases the level of discomfort and it leads an individual to engage in activities that repress the stimulation. On the other hand, if there is not enough stimulation, the stimulation decreases to undesirably low levels and causes problem. Immobilization is against the nature of organism. The stimulation mechanism that emerges during the play gives a sense of pleasure after the control of the organism. This theory explains the reasons of child behavior observed in the play process (Johnson, Christie, \& Yawkey, 1998; MoNE, 2009).

Bateson's Theory. B According to this theory, the play is against logic. The actions taken during the play are generally not the actions performed in real life. While the children have lost themselves in the fighting game, the punches they throw at each other are different from the punches that are actually thrown in real life. Before playing such a game, children have to create a play frame or environment that everyone must know about what to do in the play and what this game is not real (Johnson, Christie, \& Yawkey, 1998).

The play is the process of using old information, rearranging and configuring their information, and moreover, acquiring new information for children. Children discover the fact that the information they get from the play is really work-related through their experiences and they destroy some of them while improving themselves by using some others. As children are constantly in action, they reach a new discovery at any moment and begin to create their true meaning in the process. A situation observed as a result of a coincidence in the beginning turns into a conscious behavior (Tuğrul, 2010). Through the play, children who recognize themselves and their surroundings learn many concepts through discovery and gain life experience. The play provides to acquire the ability to collect their attention, to accelerate the functioning of mental processes such as aim for a purpose, identify and recognize objects, understand their functions, establish cause-and-effect relationship, think, perceive, sort, classify, analyze, synthesize, evaluate and problem solving, to acquire many concepts such as time, space, color, shape, weight and volume (MoNE, 2009). The play is an indispensable element of the learning process especially for young children. The play is a key learning experience that increases mental capacity, such as creativity for preschool children, and that teaches social skills and self-regulation. For older children, the play continues to support learning goals that strengthen self-regulation and literacy skills. The play helps children to become self-directed and self-motivated individuals and to enjoy learning process when used for academic experience (Bonura, 2009). Children use different cognitive strategies while playing. Children's learning skills from errors and failures reflect their cognitive strategies, and these strategies reflect problem solving and cognitive skills of children (Bow \& Quinnell, 2001).

Play is very important in child development and significantly increases learning (Carlisle, 2009). Because the play allows the child to learn how to learn (Sevinç, 2004). Two of the conditions and characteristics of learning are participation and pleasure. This shows that the best way for children to learn is being engaged in an activity they know better and they like to do and actively participating in the activity. The method, which facilitates the learning, is realized through play (Pramling-Samuelsson \& Johansson, 2006). The curiosity, desire to discover, repeated and internally controlled behaviors make the child a good learner and extend the attention span as necessary. In addition, the play reduces the level of anxiety and stress experienced in situations that lead to success and learning. Risks and penalties for faults in the play have been controlled (Sevinç, 2004). Cognitive skills such as memory, concentration, logical thinking and creative problem solving are discussed in the play. Learning new behaviors, self-reflection and self-understanding in a play are cognitive processes which are important elements of emotional development (Schaefer \& Reid, 2001). For preschool children, play is a key learning experience that teaches creativity, social skills and self-regulation, and supports cognitive capacities. Children can enjoy the learning process more when the play is used in the academic environment. The play is an energetic structure that connects thought, body and character. Children who are allowed to play freely with other children develop their cooperation, sharing, solidarity and problem-solving skills (Carlisle, 2009). The most effective method for the development of intelligence is to play games. The child learns to think, share, and make her/his own decisions, take responsibility, cooperate and develops her/his imagination, creativity and skills by playing games. She/he also has the opportunity to concentrate her/his attention on a point, to learn to recognize herself/himself and to organize her/his skills, and to get rid of her/his aggression. Consequently, play is the key to one's experiences in childhood and its role in adulthood (Turgut \& Yilmaz, 2010). In this context, Froebel (1902) stated that although the play was seen as children's work, the play was not worthless time spent by the child but rather the seeds of later life were thrown through the play in childhood (see Brosterman, 1997). All children need to play the game regardless of their age and ability. The play, which varies between children and cultures, is the primary task of children under all circumstances. Research shows that there is a strong relationship between game experience and cognitive, emotional, motor and language skills (Kindler, 2009). Child's development is contributed by supporting the play (Carlisle, 2009). Children learn more things through play (Robinson, 2008) and gain new skills and functions. The 
children reorganize their achievements during these activities and apply them to other situations by integrating them with their existing knowledge (Sevinç, 2004). In this context, play is the most necessary tool for children to gain psychomotor skills and to improve their social-emotional and language development. Every activity performed with various plays and play tools in different development periods constitutes an important step in the development of the child (Turgut \& Yilmaz, 2010). The play bridges many aspects of development. With the curiosity of the child, play is the main way of development in early childhood (Robinson, 2008).

Research has generally collected data from families, teachers and children and presented the viewpoints of these audiences to readers. Some of these studies are as follows. In the research conducted by Coolahan, Fantuzzo, Mendez, and McDermott (2000), 556 children attending the Head Start school in the USA participated in the study and were asked to complete three different scales related to learning and play. These researchers aimed to determine the extent to which problematic behaviors and learning behaviors in low-income children affect their play with their peers, it was assumed that behaviors involving positive peer interaction were positively associated with learning behaviors and negatively associated with behavioral problems within the classroom. 73 families and 60 teachers participated in the study conducted by Rothlein and Brett (1987) in order to examine the ideas of teachers, parents and children on play and determine whether their perceptions and actions are reflecting the ideas on the play being mentioned in the literature. Within the scope of the research, teachers and parents were asked to define the play. Definitions and expressions of teachers and parents related to the play can be listed as: "words related to pleasure (enjoyable, pleasant, entertaining activities), social development, learning or cognitive activity, physical activity and muscle building, creativity and imagination, unstructured activity, preparation for future roles and the child's task". In a study conducted by Hoorn et al. (2007) with preschool and classroom teachers on the implementation of a play-centered program, interviews were conducted on how teachers perceived the play first. In another study by Pilten and Pilten (2013); children's perception of play was assessed by semi-structured interview questions. The purpose of Tuğrul, Aslan, Ertürk, and Altınkaynak (2014) research is to present the opinions and expectations of 6-year-old children and preschool teachers in early childhood. The study of Rentzou et al. (2018) investigates whether the conceptualization of the play affects play uses; it also examines the similarities and differences in conceptualizations and uses them across countries.

The Preschool Curriculum (MoNE, 2013) attaches great importance to children's games. Children are defined as AR play experts cocuk and play as children's job and language. The play has a two-way goal: (1) to learn (or teach) some skills and (2) to meet the needs of children. There are three types of play: free play (at the beginning and end of the day), semi-structured play events (creative play) and structured play events (traditional games with rules) (see Rentzou et al., 2018). When we consider the play as a task of a child and the life as a way of learning, the use of this entertaining and child-centered method in education is inevitable. For this reason, it is important to have knowledge about teachers' use of play as a teaching method in the primary school period where the foundations of the educational life are laid (Özyürek \& Çavuş, 2016). It is seen that the value and importance given by the classroom teachers to the play in primary schools, which is the next step for preschoolers, are related with the teachers' use of play as a method of teaching. The teachers, who had participated the research conducted by Özyürek and Çavuş (2016) with the purpose of examining the use of play as a teaching method with the classroom teachers, stated that the most effective teaching methods for children are learning by doing and learning by experience methods, followed by a play method. It was found that teachers did not keep the play in the first place among active learning methods. This research aims to reveal the perceptions of the preservice teachers on play which is among the basic needs of the preschool children.

\section{Method}

\subsection{Research Model}

In this descriptive study, case study method, which is one of the qualitative research designs, is used. Qualitative research is defined as research, where observation, interview and document analysis are carried out together with information collection methods, and a qualitative process is followed in order to present perceptions, situations and events in a holistic way in natural environment (Yıldırım \& Şimşek, 2006).

\subsection{Participant (Subject) Characteristics}

79 preservice teachers attending the third grade in the Classroom Teaching Department of state university in Nigde province in Turkey in the academic year of 2017-2018 formed the study group. Nine participants of the study group were male. In order to prevent participants from responding to the research questions in a biased way, it was taken into the consideration that they did not take the early childhood education course in which they learned detailed information about preschool children but took physical education and play teaching courses. Thus, the status of considering the play, which they knew as a teaching method, as a need of children was determined. 
Convenience sampling method was applied in the selection of the study group. Convenience sampling selects accessible participants rather than finding participants randomly from a well-defined universe (Warner, 2008).

\subsection{Data collection}

The interview is used to learn about behaviors, emotions that cannot be observed directly or how people express the world around them. In qualitative studies, the required information can be collected through interview (Ekiz, 2003). The principle of volunteerism was taken as a basis for the participation of preservice teachers. A two-page semi-structured interview form was prepared to determine the perceptions of preservice teachers about the play. In the interviews conducted with the preservice teacher, they are expected to complete the sentence of "The play is important, because..." on the second page of the form, after writing down the three of the essential needs of preschool children on the first page. Thus, it was determined from the data obtained that the reasons attributed by preservice teachers for the importance of the play. The reliability of the semi-structured interview form was provided by applying to the seven preservice classroom teachers selected by random sampling method. After determining that the semi-structured interview form was appropriate for the purpose of the study, the main application was initiated.

\subsection{Data Analyses}

The main objective of qualitative data analysis is to reveal the information that is concealed in social reality (Özdemir, 2010). Accordingly, qualitative research analysis was used in the analysis and interpretation of the data obtained in the research. For the analysis of data, content analysis technique was used. The responses obtained from the forms are coded and categorized. In the content analysis, first of all, the researcher considers the words, sentences or pictures in the categories developed by the researcher in the data set (Özdemir, 2010). These data were coded independently by the researcher and an assessment expert and the consistency between the coders was obtained. Then, themes that are appropriate to the categories were determined and the findings examined under the theme headings were interpreted. In the interpretation of the findings, direct quotations from the opinions of the participants were tried to be validated.

\section{Results}

As a result of the analysis of the data obtained from the research, the items that the preservice teachers listed as the essential needs of the preschool children are presented in Table 1.

Table 1. Distribution of essential needs of preschool children by preservice teachers

\begin{tabular}{lc}
\hline & $\mathrm{f}$ \\
\hline Food (nutrition) & 33 \\
Education (learning, reading, task) & 31 \\
Love (being loved, feeling valuable) & 30 \\
Play (toy) & 29 \\
Accommodation (protection) & 23 \\
Entertainment (socialization, spending time together, eating, cinema, playground, TV, PC, holiday) & 21 \\
Talking (conversation, self-expression, communication, knowledge acquisition, asking, curiosity) & 13 \\
Attention (being cared, being heard) & 10 \\
Morality (solidarity, moral, respect, politeness, tolerance) & 9 \\
Trust (self-confidence) & 9 \\
Dressing & 8 \\
Rest room(cleaning) & 6 \\
Materiality (shopping) & 6 \\
Problem-solving (accomplishment) & 4 \\
Fulfilling the responsibilities & 2 \\
Sleeping & 1 \\
Health & 1 \\
\hline
\end{tabular}

When Table 1 is examined, it was determined that the preschool period teachers expressed the students' essential needs as nutrition, education and love respectively. The play was ranked as the number four among these needs. In addition, it is seen that accommodation and entertainment needs were mentioned among the other needs. Another significant finding of the study is that the need for sleep, cleaning, trust and accomplishment are included among the least stated needs. 
Findings related to the causal attribution of preservice teachers on importance of the play are given in Table 2 .

Table 2. Causal attributions on importance of the play

\begin{tabular}{|c|c|c|c|c|c|c|c|}
\hline Taking pleasure & & $\begin{array}{l}\text { Interpersonal } \\
\text { Communication } \\
\end{array}$ & & Learning & & Development area & \\
\hline Being Happy & 11 & Self-expression & 6 & Learning social skills & 12 & Cognitive development & 7 \\
\hline Imagination & 10 & Socialization & 5 & $\begin{array}{l}\text { Learning } \quad \text { by } \\
\text { entertaining }\end{array}$ & 7 & Psychomotor development & 7 \\
\hline Freedom & 5 & $\begin{array}{l}\text { Spending time with } \\
\text { friends }\end{array}$ & 5 & Learning new things & 6 & All developmental areas & 5 \\
\hline Enjoying the childhood & 5 & Interaction & 4 & $\begin{array}{l}\text { Revealing the } \\
\text { abilities }\end{array}$ & 4 & Language development & 2 \\
\hline Self-confidence & 4 & Making friendship & 3 & Intelligence & 3 & Character development & 2 \\
\hline $\begin{array}{l}\text { Revealing the } \\
\text { subconscious }\end{array}$ & 4 & Active participation & 3 & Thinking skills & 3 & Emotional development & 2 \\
\hline Entertainment & 3 & $\begin{array}{l}\text { Spending time with } \\
\text { family }\end{array}$ & 3 & Obeying the rules & 3 & Total & 25 \\
\hline $\begin{array}{l}\text { Feeling of competition } \\
\text { (losing-winning) }\end{array}$ & 3 & Being supported & 2 & Recreation & 1 & & \\
\hline $\begin{array}{ll}\text { Surplus } & \text { energy } \\
\text { consumption } & \end{array}$ & 2 & $\begin{array}{l}\text { Child recognition } \\
\text { means }\end{array}$ & 1 & Total & 39 & & \\
\hline Creativity & 2 & Total & 32 & & & & \\
\hline Curiosity & 1 & & & & & & \\
\hline Total & 50 & & & & & & \\
\hline
\end{tabular}

When Table 2 is examined, as a result of the analysis of the data related to the sentence "The play is important, because...", it was determined that they attributed the importance of the play on four different reasons. These are pleasure (50), learning (39), interpersonal communication (32) and development areas (25). Most of the preservice teachers, who addressed importance of play through the learning aspect, emphasized learning social skills (12) and learning by entertainment (7), while those, who addressed the importance of play by pleasure, stated that the play is important in terms of being happy (11) and imagination (10). The preservice teachers, who found the play important in terms of supporting the development areas, specifically stated the names of cognitive (7) and psychomotor (7) development areas.

The opinions of the 1st, 19th, 27th and 29th preservice teachers explaining the importance of the play by supporting the development areas are as follows:

"The play is important. Because children use cognitive skills, while they will think and imagine in the play processes." (ÖA1)

"The play is important, because it enables children to think." (ÖA19)

"The play is important, because the child acquires language skills and facilitates the child's self-expression process." (ÖA27)

"The play is important, because it allows the child's weak muscles to develop and to discharge the excessive energy." (ÖA29)

The opinions of the $2^{\text {nd }}, 10^{\text {th }}, 33^{\text {rd }}, 57^{\text {th }}$ and $61^{\text {st }}$ preservice teachers attributing the importance of the play by the reason of pleasure are as follows:

"The play is important, because it allows the child to express her/his thoughts in the inner world through play." (ÖA2)

"The play is important, because it allows the child to grow happily. "(ÖA10)

"The play is important, because it allows the child to make effort by creating a sense of competition for the child." (ÖA33)

"The play is important, because children leave their marks on the play, while playing games." (ÖA57) 
"The play is important, because the child is as free as possible in all respects." (ÖA61)

The opinions of the $7^{\text {th }}, 32^{\text {nd }}, 50^{\text {th }}$ and $73^{\text {rd }}$ preservice teachers considering the play important in terms of being an interpersonal communication tool are as follows:

"The play is important, because it establishes a link between the child and the family." (ÖA7)

"The play is important, because it is a vital resource for getting information from the child about her/his physical and psychological structure."(ÖA32)

"The play is important, because the play is the way the child expresses herself/himself and her/his life experiences." (ÖA50)

"The play is important, because the children express themselves through play."(ÖA73)

The opinions of the $13^{\text {th }}, 28^{\text {th }}, 35^{\text {th }}, 45^{\text {th }}$ and $64^{\text {th }}$ preservice teachers attaching importance to the role of the play in learning are as follows:

"The play is important, because it allows the child to think more logically." (ÖA13)

"The play is important, because children learn a lot through the play (sharing, assignment, imitation...)" (ÖA28)

"The play is important, because it allows the child to learn by entertaining." (ÖA35)

"The play is important, because it enables children to use their spare time left from course hours and some other responsibilities." (ÖA45)

"The play is important, because it improves the intelligence of children." (ÖA64)

\section{Discussion}

As a result of this study, which aims to reveal the perceptions of preservice teachers about play among the essential needs of preschool children, it has been observed that the preschool children 's essential needs were primarily nutrition, education, love, and the play ranked fourth in this ranking. In addition, it was determined that preservice teachers attributed the importance of the play to four different reasons.

When the answers of preservice teachers about the importance of the play are examined, it is seen that these answers support the theoretical information. For example, "discharging the excessive energy" is related to the Surplus Energy Consumption Theory, "recreation, entertainment, being happy" are related to the Relaxation Theory, "revealing the subconscious" is related to the Freud's Theory, "learning social and emotional development, cognitive development, self-confidence, use of language, memory, imagination, obeying rules, social skills" are related to the Vygotsky's Theory, "creativity, imagination, freedom, curiosity" are related to the Bruner's Theory, "imagination" is related to the Singer's theory, "learning new things, discovering the skills, making friendships, creativity, curiosity" are related to the Sutton-Smith's Theory, "learning by entertainment, thinking skills, creativity" are related to Bateson's Theory, "competition sense(losing-winning)" is related to the Intrinsic Stimulation Theory, "intelligence, thinking skills, cognitive development" are related to the Piaget's Theory, "obeying rules, being supported" are related to the Practice Theory, "all development areas, making friendships, spending time with friends, spending time with family, self-expression" are related to the Erikson's Theory.

As a result of Coolahan, Fantuzzo, Mendez, and McDermott's (2000) research, it was determined that children who exhibited positive peer interaction behaviors were also active in classroom learning activities and they showed high motivation, attention and positive attitude towards learning compared to those who did not play. Children with high levels of negative behaviors in the classroom also showed hyperactivity and problematic behaviors in classroom activities. It has been observed that the findings showing that the children who play have a positive attitude towards learning overlap with the preservice teachers' emphasis that the play is necessary for learning. In the study conducted by Rothlein and Brett (1987), the most frequently used expressions by parents were "pleasure, amusement or entertainment", whereas the teachers were considering the play as an opportunity not only for entertainment but also for social and cognitive development. The parents were asked why they gave so much time for the play and their answers were divided into three categories. The first reason is that, according to parents, children need to do other things rather than needing play time. The second reason is that children need to play as a rest by emphasizing the difference between work and play. The third reason is the positive aspect of the play. Most of the parents and teachers examined in the study considered the play important for children. In this study, when asked about the importance of the play to the preservice teachers, it was found that the most common answers were to get pleasure. As a result of the study by Pilten and Pilten (2013), it was determined that the basic 
criterion used by children to decide whether or not any activity was a play was fun. Stressful environments, mandatory participation and management in adults prevent children from participating in play. Likewise, in addition to the pleasurable nature of the play, it was emphasized that the play supports the areas of learning and development. In this context, it can be said that even if the cultures change, the thoughts and importance of the play will not change. It is thought that the participants did not only predicate the play to entertainment and pleasure but also addressed the contributions of play to development and learning, as the study group consists of preservice teachers and individuals from the education field, the play is seen as an important value for learning. In this study, and in the studies of Pilten and Pilten (2013) and Rothlein and Brett (1987), there are overlapping results related to the teachers and whether the finding of parents' separating the play and work and allocating time for play in the remaining time from work is also valid for Turkish parents or not may arouse curiosity for the future studies.

As a result of the interviews which conducted by Hoorn et al. (2007), it was found that the teachers perceive the play as a social environment where children could share their feelings and thoughts, an opportunity for children to make their own decisions and choices, the moments children with special needs to express themselves easily, to feel themselves valuable and a significant period of time for them to observe children profoundly for recognizing them. Similarly, in this study, some of the preservice teachers (32) stated that the play was valuable in terms of socialization, interpersonal communication, and recognition of children. It can be said that preservice teachers are aware the fact that the play supports children's social and emotional development. In this regard, the preservice teachers can continue to use the play as a social emotional development support in their professional life. Participation in practical workshops can be ensured in order for each preservice teacher to see and transfer this aspect of the play to the professional life. Studies to identify and increase awareness of families can be performed.

According to the research of Tuğrul, Aslan, Ertürk, and Altınkaynak (2014), it was seen that children and teachers emphasized similar features about play definitions. It is seen that teachers exhibit the attitude and behaviors such as giving the play to children as a resting time or as a reward and easily interrupting the play in order to realize other activities. This causes children to see adults outside the play. It is seen that the teachers do not realize the importance of the play in the education program and they do not benefit from the play as an active teaching method. However, in this study, preservice teachers stated that play should be used for entertainment not to discipline and formal education.

The results of Rentzou et al. (2018) study revealed the existence of both universal and non-universal play features. However, despite the existence of universal characteristics, differences have been revealed to the extent that they speak across countries. Differences have been identified in terms of how early childhood educators influence their opinions on children's play in early childhood programs. Various relationship models between definitions and uses have been revealed. Some countries seem to have been characterized by a play ethos' of how the game is conceptualized and used, whereas others seem to be struggling between a more instructive approach initiated by the teacher and the introduction of a more child-initiated, play-based curriculum. In this study, which supports study of Rentzou et al. (2018), preservice teachers stated that play should be child-centered and fun-based.

Considering that the majority of children's perceptions of the play are influenced by the attitudes and behaviors of teachers, the necessary measures should be taken for preservice teachers to increase the intensity and quality of the games by taking the play as seriously as the other activities. These measures can be listed as including the content of the play course that the preservice teachers take during their undergraduate education as practical as the least theoretical knowledge, encouraging their participation in the workshops on the play, and often including the play as a teaching method in the other courses. On the other hand, families should exhibit attitudes-behaviors that value their children's play and make this attitude felt for their children and families should be supported in this issue.

\section{References}

Bodrova, E., \& Leong, D. J. (2010). Zihnin araçları: Erken çocukluk eğitiminde Vygotsky yaklaşımı [Tools of the Mind: Vygotsky approach in early childhood education]. Çev. T. Güler, F. Şahin, A. Yılmaz ve E. Kalkan, Ankara: Anı Yayıncılık.

Bonura, K. (2009). Academic Learning and Play. In R. Carlisle (Ed.), Encyclopedia of play in today's society. London: Sage Publications. https://doi.org/10.4135/9781412971935.n1

Bow, J. N., \& Quinnell, F. A. (2001). Therapeutic uses of fine motor games. In C. Schaefer, \& S. E. Reid (Eds.), Game play therapeutic use of childhood games (2nd ed.). New York, NY: John Wiley \& Sons, Inc.

Brosterman, N. (1997). Inventing kindergarten. New York: Abrams/Times Mirror.

Carlisle, R. P. (2009). Encyclopedia of play in today's society. London: Sage Publications. https://doi.org/10.4135/9781412971935 
Coolahan, K. C., Fantuzzo, J., Mendez, J., \& McDermott, P. (2000). Preschool peer interactions and readiness to learn: Relationships between classroom peer play and learning behaviors and conduct. Journal of Educational Psychology, 92, 458-465. https://doi.org/10.1037/0022-0663.92.3.458

Daw, J. (2009). Anti-Competition Play. In R. Carlisle (Ed.), Encyclopedia of play in today's society. London: Sage Publications. https://doi.org/10.4135/9781412971935.n21

Egemen, A., Yılmaz, Ö., \& Akil, İ. (2004). Oyun, oyuncak ve çocuk. [Games, toys and children]. ADÜ Tip Fakültesi Dergisi, 5(2), 39-42.

Ekiz, D. (2003). Eğitimde araştırma yöntem ve metodlarına giriş: Nitel, nicel ve eleştirel kuram metodolojileri. [Introduction to research methods and methods in education: Qualitative, quantitative and critical theory methodologies]. Ankara: Anı Yayıncılık.

Ginsburg, K. R. (2007). The Importance of Play in Promoting Healthy Child Development and Maintaining Strong Parent-Child Bonds. American Academy of Pediatrics, 119(1), 182-191. https://doi.org/10.1542/peds.2006-2697

Hoorn V. J., Nourot, M. P., Scales, B., \& Alward, R. K. (2007). Play at the center of curriculum (4th ed.). Pearson Merrill Prentice Hall, Upper Saddle River, New Jersey.

Johnson, J. E., Christie, J. F., \& Yawkey, T. D. (1998). Play and childhood development (2nd ed.). New York, NY: Longman.

Jones, M. (2001). Oyun ve çocuk [Play and children]. Çev., Ayda Çayır. İstanbul: Kaknüs Yayıncılık.

Kamaraj, I. (2000). Okul öncesi eğitimde oyuncak kütüphanesi [Toy library in preschool education]. Marmara Üniversitesi Ĕ̈itim Bilimleri Dergisi, 177-182.

Kelly-Vance, L., \& Ryalls, B. O. (2008). Best practices in play assessment and intervention. In J. Grimes, \& A. Thomas (Eds.), Best practices in school psychology $V$ (Vol. 2, pp. 549-559). http://www.nasponline.org/publications/booksproducts/BP5Samples/549_BPV71_33.pdf

Kindler, V. (2009). Adaptive Play. In R. Carlisle (Ed.), Encyclopedia of play in today's society. London: Sage Publications.

Lockhart, S. (2010). Play: An important tool for cognitive development. HighScope Extensions Curriculum Newsletter, 24(3). Retrieved from http://membership.highscope.org/app/issues/142.pdf

Ministry of National Education (MoNE). (2013). Preschool education program. Ankara, Turkey.

MoNE. (2009). Çocuk gelişimi ve eğitimi, Oyun etkinliği-1 [Child development and education, Play activity-1]. Retrieved from http://megep.meb.gov.tr/mte_program_modul/modul_pdf/761CBG021.pdf

Nicolopoulou, A. (2004). Oyun, bilişsel gelişim ve toplumsal dünya: Piaget, Vygotsky ve sonrası. [Play, cognitive development and social world: Piaget, Vygotsky and after]. Çev. M. T. Bağl, Ankara Üniversitesi Eğitim Bilimleri Fakültesi Dergisi, 37(2), 137-169.

Özdemir, M. (2010). Nitel veri analizi: Sosyal bilimlerde yöntembilim sorunsalı üzerine bir çalışma [Qualitative data analysis: A study on the methodology problem in the social sciences]. Eskişehir Osmangazi Üniversitesi Sosyal Bilimler Dergisi, 11(1), 323-343.

Özyürek, A., \& Çavuş, Z. S. (2016). İlkokul öğretmenlerinin oyunu öğretim yöntemi olarak kullanma durumlarının incelenmesi [Examination of using the play of primary school teachers as teaching method]. Kastamonu Education Journal, 24(5), 2157-2166.

Pilten, P., \& Pilten, G. (2013). Okul çağı çocuklarının oyun kavramına ilişkin algılarının ve oyun tercihlerinin değerlendirilmesi [Evaluation of school age children's perceptions about game concept and play preferences]. Mersin Üniversitesi Eğitim Fakültesi Dergisi, 9(2), 15-31.

Poyraz, H. (2003). Okul öncesi dönemde oyun ve oyuncak [Play and toys in preschool]. Ankara: Anı Yayınc1lık.

Pramling-Samuelsson, I., \& Johansson, E. (2006). Play and learning-inseparable dimensions in preschool practice. Early Child Development and Care, 176(1), 47-65. https://doi.org/10.1080/0300443042000302654

Rentzou, K., Slutsky, R., Tuul, M., Gol-Guven, M., Kragh-Müller, G., Foerch, D. F., \& Paz-Albo, J. (2018). Preschool Teachers' Conceptualizations and Uses of Play Across Eight Countries. Early Childhood Education Journal, 47(1), 1-14. https://doi.org/10.1007/s10643-018-0910-1

Robinson, M. (2008). Child Development 0-8: A journey through the early years. New York, NY: Open 
University Press.

Rothlein, L., \& Brett, A. (1987). Children's, teachers' and parents' perceptions of play. Early Childhood Research Quarterly, 2(1), 45-53. https://doi.org/10.1016/0885-2006(87)90012-3

Schaefer, C., \& Reid, S. E. (2001). Game play: Therapeutic use of childhood games (2nd ed.). Toronto: John Wiley \& Sons.

Sevinç, M. (2004). Erken çocukluk gelişimi ve eğitiminde oyun [Play in early childhood development and education]. İstanbul: Morpa.

Tuğrul, B. (2010). Oyun temelli öğrenme [Play-based learning]. In R. Zembat (Ed.), Okul Öncesinde Özel ögretim yöntemleri, Ankara: Anı Yayıncılık.

Tuğrul, B., Aslan, Ö. M., Ertürk, G., \& Altınkaynak, Ş. Ö. (2014). Anaokuluna devam eden altı yaşındaki çocuklar ile okul öncesi öğretmenlerinin oyun hakkındaki görüşlerinin incelenmesi. İönü Üniversitesi Eğitim Fakültesi Dergisi, 15(1), 97-116. https://doi.org/10.17679/iuefd.05509

Turgut, H., \& Yılmaz, S. (2010). Ekolojik temelli çocuk oyun alanlarının oluşturulması [Creation of ecologically play based children playgrounds] (pp. 1618-1630). III. Ulusal Karadeniz Ormanculık Kongresi, Artvin.

Verenikina, I., Harris, P., \& Lysaght, P. (2003, July). Child's play: Computer games, theories of play and children's development. In Proceedings of the international federation for information processing working group 3.5 open conference on Young children and learning technologies (Volume 34, pp. 99-106). Australian Computer Society, Inc..

Warner, R. (2008). Applied statistics from bivariate through multivariate techniques. Los Angeles: Sage Publications.

Yıldırım, A., \& Şimşek, H. (2006). Sosyal bilimlerde nitel araştırma yöntemleri [Qualitative research methods in the social sciences] (6. bask1). Ankara: Seçkin Yayıncılık.

\section{Copyrights}

Copyright for this article is retained by the author(s), with first publication rights granted to the journal.

This is an open-access article distributed under the terms and conditions of the Creative Commons Attribution license (http://creativecommons.org/licenses/by/4.0/). 